\title{
EXPERIMENTAL STUDY OF CALORIC TEST ON THE SUPERIOR SEMICIRCULAR CANAL
}

By

\section{TANAKA}

From the Department of Oto-Rhino-Laryngology, Nippon Medical School (Director: Prof. T. Daito)

A considerable amount of research has been reported on the caloric test for the function of the horizontal semicircular canal, but little work has been done on the caloric test for those of the vertical semicircular canal. After a special surgical operation of the semicircular canal, the superior semicircular canal of rabbit was examined under various kinds of caloric stimuli by using the new apparatus which the author had made to give caloric stumulus to the semicircular canal. It was observed that severe vertical nystagmus appeared when the unilateral superior canal was stimulated and slight rotatory nystagmus appeared when the bilateral superior canal was done simultaneously. On the other hand when caloric stimulus was given to the unilateral superior semicircular canal, rotatory nystagmus appeared in man. Concerning with this reason the author presumed that it might be caused by the difference of anatomical situation of the semicircular canal and the eyeball between in men and in rabbits.

\section{前垂直半規管冷温剌戟による眼球振盪の実験的研究}

\section{日本医科大学耳兽咽院科教空（主任：大藤敏三教授）}

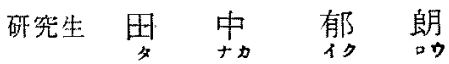

$$
\begin{aligned}
& \text { 目次 } \\
& \text { 第1率耤䨐 } \\
& \text { 第 } 2 \text { 草 人体における来鮯 }
\end{aligned}
$$

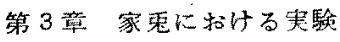

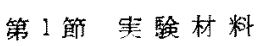

$$
\begin{aligned}
& \text { 第2 節 実蹒方法 } \\
& \text { 第 } 3 \text { 節 灌流装置 }
\end{aligned}
$$

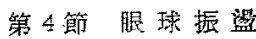

$$
\begin{aligned}
& \text { 第1項 H耳刺戟 } \\
& \text { 籍 } 2 \text { 项 最小献戙間值 } \\
& \text { 第 } 3 \text { 项 雨唰耳同封刺戟 }
\end{aligned}
$$

$$
\begin{aligned}
& \text { 第4 章 考按 } \\
& \text { 第 5.喜結諭 }
\end{aligned}
$$

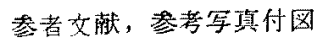

\section{第 1 章 緒言}

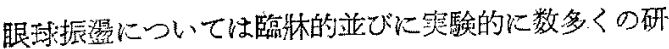
究報告があり，半規管の機能も次第に究明されてきてい るが，これら大部分の報告は殆ど止平半规管と水平性眼

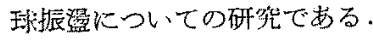

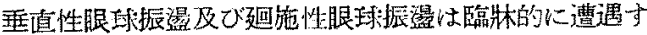

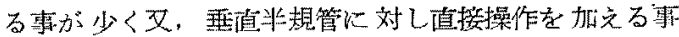
が解剖学的に困難なため，多くの研究報告なるないが Mygund (1931)，山阴 (1940) 等は垂值性眠球振盗の

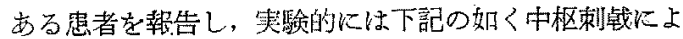

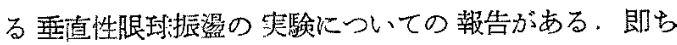
Berrene (1923) 快犬，猫を用い小畄を半剔出. Spiege u. Sato (1927) は犬. Klosowsky (1934) は猫. 松下 (1938) 汇家鬼. Dow (1938) は猿. Spiegel and Scala (1942) は桼、についで゙イテル核べヒテレフ核に損㑺

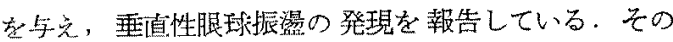

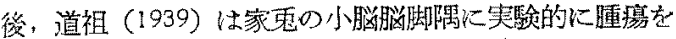

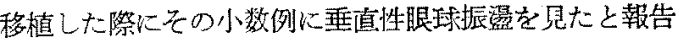

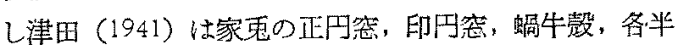

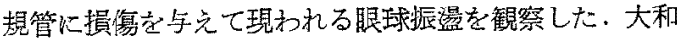
田（1952〜8）は猬について前庭核及びとの伝導路の損 矰による重直性眼球振盪について報告をしている。 
一方，冷温刺钱を水平半规管に与えた場合の腿球振琶 については Schmiedekan und Hansen (1868) の観 察に始亲り Spamer (1880), Babinsky (1飞81), Barany (1940), Ewald, 久保等を経て理論が解明され吉 田, 斎藤は水.平半规管葷腹部に限局刺战を与完安田

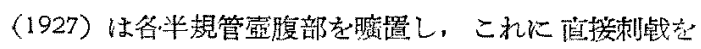
与えて限球筋の荤動を検查している。

しかし，水平半規管冷温刺战 $\rightarrow$ 水平半規管内潹巴流䧿 $\rightarrow$ 水平性眼球振湯，と同じょうに金直半規管冷温刺㦸 $\rightarrow$ 垂直半規管内淋巴流動 $\rightarrow$ 眼球振盪と言う事は当然考兄ら れながら、未だ詳細に見究めた報告を見ない

こ〉において著者は人体及び家乘について垂植半规管 に直接冷温刺战を与えてその結果を镜察せんと经力一连 の成果を得たのでこ〉に報告する。

\section{第 2章 人体における実験}

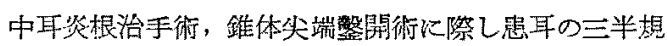
管が周国慢性焱定の波及により既汇との機能を失つてい、 るむのであれば，その病的半規管を䅡極的に除去する事 により更に梁部の病栄を究める事が容易にになると考劣 各三半規管別に健否をはかるため冷温刺㦸を与えて眼球 振盪を検查した。

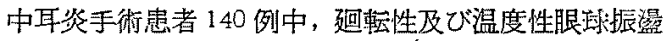
正常で且蜂畓の発育良好, 病的化骨榰骨の少いるのを選 定 12 例の適応例を得これについて笑験を行つた．中耳 炎根治手術, 錐体尖端籢開術（フマジエ，ストライト， 仁保，平野，フオス氏法等を併用）を徹底して施行し三 半規管骨を浮彫りにした後, 大脳小脳脳膜を広く露出し これを圧迫举上し各半規管骨壁を開空術用の Burr を用 いて薄く削除する.前半規管では大脳との間に, 後半規 管では小脳との間に付図 1 の如き㴶流淩犆を挿入しガー ビタンポンで装置を圧迫固定し切開創を縫合する，

濯流装置は内径 $1 \mathrm{~mm}$ の銅管 $2 \mathrm{~cm}$ をU 宇状に曲げ 両端にビニール管を付け，中を液体を通す事ができる うに自製したものである，付図 2 は前半規管上部に付图 3は後半規管後部にこの灌流洨置を舫入した手術後のレ ンド゚ン写真である。

手術後第 2 日上り第 4 日迄の間に㭧者を坐位に置きこ の潅流㳖置の中を $45^{\circ} \mathrm{C}, 27^{\circ} \mathrm{C}, 20^{\circ} \mathrm{C}, 10^{\circ} \mathrm{C}$ の冷温水を

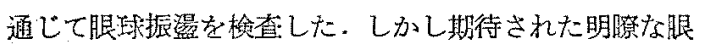

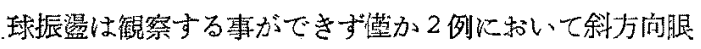

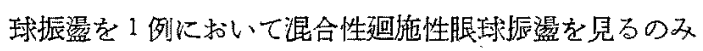
であつた．この失敗は半規管内淋巴に与克あるいはこれ 上り留う熱量の不足即ち半規管筒壁の削险の不足文は,
整流管の㹟小に上る液流量の不足，更にはガーゼタンボ ンの湿潤により灌流管の熱がガーゼタンポンや脳実質に 筫はれて了う事等に由来するるのと考光られる。こつで 㬰駼材料の不足を痛感し改めて動物実験より踏灭出す重 とし家恙を用いて前半规管に淔接に冷温刺战を与克て綎 方向の腿球振盕を明確に発現せしめる事ができた。

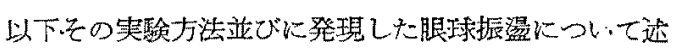
ベる.

\section{第3 草 家兔における実験}

第 1 節 奏驗材料

各種動物の内耳構造を比較したところ家鬼では前半規 管が頭蓋腔内殆ど露出し，その骴壁も非常に薄く且つ 半規管の輪の中を小腷小葉が通り抜けている事（付図

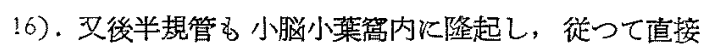
これらに刺戟を与兄る操作が容易であるら事に注日し， これを選ぶ事とした。

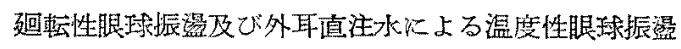

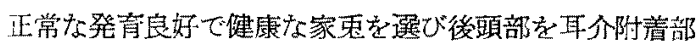
迄别毛する。

第 2 節 実路方法

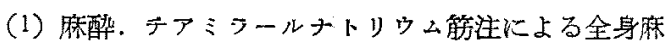
䣲とニピレナミン抓プロカイン局所注射䏫酔併用. エ 一テルは頭部手術と微細な操作を施行するのに不便なの で便用しなかつた。シアミシーナトリウムは体重 $1 \mathrm{~kg}$ につき 1 回 25〜 50mg を 15 30 分間隔で 2〜6回能注

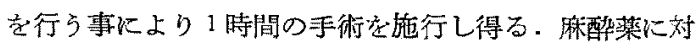
する抵抗性の個差は非常に大きく全量を一概に定める事 はできない。

（2）手術. 頭蓋頂上り後頭結節を越觉 $4 \sim 5 \mathrm{~cm}$ の縱

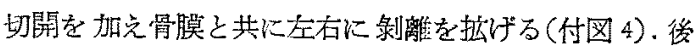
頭結節を充分代露出しその出側の四宿した僯部に付着す る後頭筋を細小銧题で剥離する. 径 5〜 7 $\mathrm{mm}$ の粗造な 円形凸骨面を露出させる事ができる（付図 5)。この骨 壁は脆く時には非常に薄い事もあり強力に鋭匙を用いる と破損して内部の小脳を損傷する事がある. 又粗造捂面 の剥離を必要以上に抬大寸ると耳介附着部に近い,動脈を 損傷し出血に遖まされる永がるる。この粗造凹骨面を内

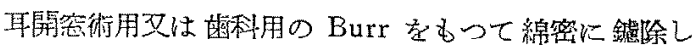

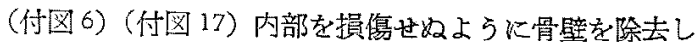
て行く上，か流り強数な骨膜脳膜に覆はれた小脳の上後 面が現はれる，この露出した脳臊に添つて残存する薄い 骨壁を細鋭题で 手前に除去し孔を兹大して径 4 6mm の円形及至棈円形の骨孔を作る。 
この骨穿孔より鋼䠌を曲げて自慗した細小スパーテル

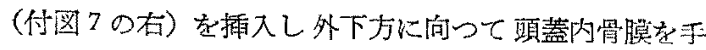
さぐりで剥離を進めると小隆起を越えて抵抗が無くな る. 前半規管後縁を越えて小脳小菒茎部に達した訳であ 万（付图 8)（付図18，19）。一二の場合，頭蓋頂骨を

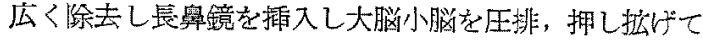

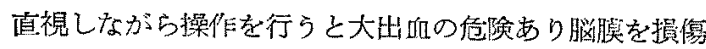
する事も多からたので上記の方法を上る事とした。一 更に先端を画在に曲け゚た 細小スーバテル（付图７のt） を乗入し先述した抵抗を失つた部位から多下方に向い小

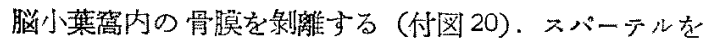
拔き同所に自製した灌流装置（後述）を插入し蔽流装置 の鈎を前半規管輪に引掛けると整流装置は強く引いても 报洋る事がない（付図 21）。灌流淩置の附属ピ ニール

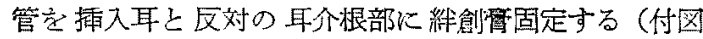

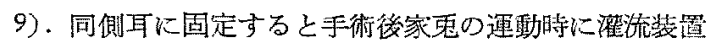

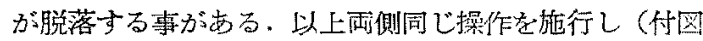
10）皮膚を縫合する（付図 11）。

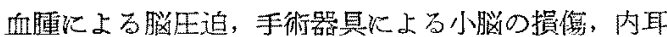
道第 8 神経附近の損傷等がある麻酰学觉醒時に眼球振 盪，眠球偏位，耳介偏位，頭部捻呿などの異常反応を呈 し激しい時は自発的横転を行つて䑁縛固定するをで横忶 を続ける。

この手術に際して最大の障碍は出血であるが上記の如 く骨破壊及び頭蓋内媨朕剥離を最小限に止める万法をと れば僅か2 2 5 cc の出血量を見るのみである. 初期に佫. 踾止血剂を使用した例では血液凝固力が堌すと頭蓋腔内 に血腫を作る事が多くこの血睡心上る小脳任迫が異常眼 球振湿を発現せしめる事があるので保用しない事とし た。

（3）手術後の状態. 手術後 2 時間以内に覚醒し飼料音 与えれば平常之同様に摄取する。この時限球の偏位なく 瞳孔正常で異常体動，運動障碍が胃られれければ手術は 戌功したるの子考觉られる。

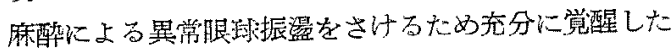

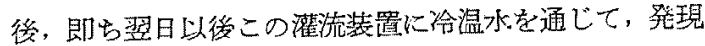

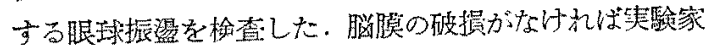
鬼は2 週間以上正常の状態で生存し少くとす10日は冷 温刺战の实験に供する事ができた。

第3節 灌流皎置(付図12著渚考案)

外径 $1 \mathrm{~mm}$ の銅管 $1 \mathrm{~cm}$ をU等状に曲げ更にこの下 端 (円端)を匙の如く曲げて扔く. 別に $0.2 \mathrm{~mm}$ 惩の鋼

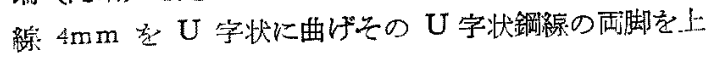

記U 字状銅管の円端に出側に向附着固定して鈎とす

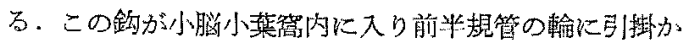
るので灌流婊置が脱落し難くなる(付図 13).

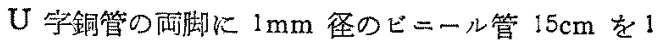
本つつ附着すればビニール管を゙通じてU 字状銅管の中 索液体を通す来策ができる。

第 4 節 眼球振湯

水平半規管に拈いては数多くの温度性腿诪振蕰の垁験 が行われ Barany の確立した内淋巴流動説を高附けて

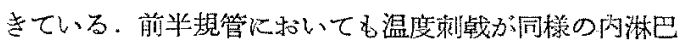

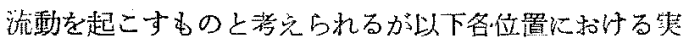
験の結果を述べる。

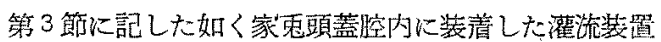
のビニール管の一方上り冷温水を圧迫注入すると鸰温水 は有鈎銅管内を通り他側ビニール管を通じて輌び外に排 出される（付図 14），有鈎銅管は前半規管に泌着してい るので薄い、骨壁を通じて内淋巴の温度に変化を与える接

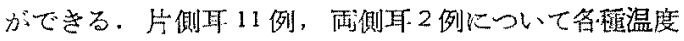

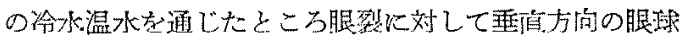

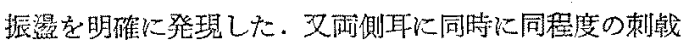
そ与克たとこ万特異な眼症状を呈した。

第1 項 片耳刺㦸（表 1)

1) 強刺㦸. $20^{\circ} \mathrm{C}$ 冷水 $4 \mathrm{cc} / 10$ 秒 (体温との差 $18^{\circ} \mathrm{C}$ )

(A) 腹位固定頭部過伸展位（番尖上位即ち上问き） 注皮開始後約 2 秒で同側眼球上方，他側眼珑下方儿偏 位，同時に頭部索他側方に捻転. 次いで同儧腿球下方に

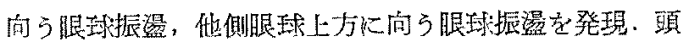

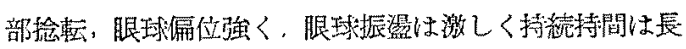
6(付图 15).

(B) 腹位固定頭部下屈折位（鼻尖下位即方下向き）

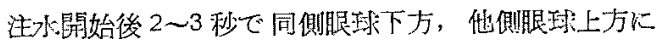

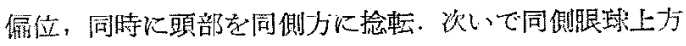

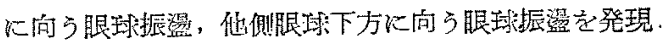

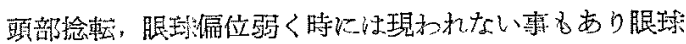

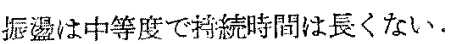

2) 弱刺㦸の (1) $30^{\circ} \mathrm{C}$ 冷水 $5 \mathrm{cc} / 10$ 秒（体温上の差 $8^{\circ} \mathrm{C}$ )

(A)腹位固定頍部過伸 展位（奥尖上位即亏上向 き)

注止開始後 3 4 秒で 同側眼球上方, 他側腿球下方に 偏位，同時に頭部を他側方に軽く揄転，炊いで同側眼球

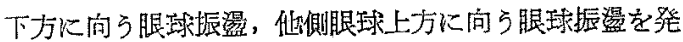
犋. 頭部揄転，眼球偏位は弱く時には現れない事もあり 


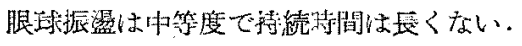

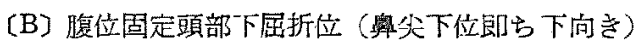

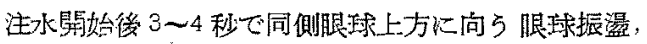

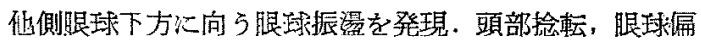
位は殆ど現れす眼球振壍は弱く時には現れない事もあり 持続時閪姑短い。

3) 弱刺㦸の (2) $45^{\circ} \mathrm{C}$ 温水 $5 \mathrm{cc} / 10$ 秒（体温との差 $\left.7^{\circ} \mathrm{C}\right)$

(A) 腹位固定頭部過伸展位（鼻尖上位即々上向き）

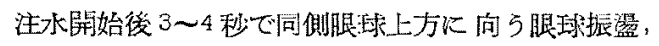

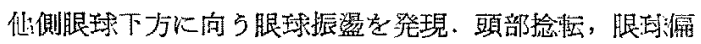

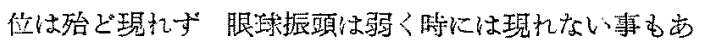
り秲続时間は逗い。

〔B）腤位固定頍部下屈折位（奥尖下位即方下向き）

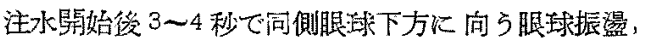

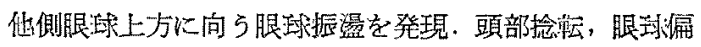

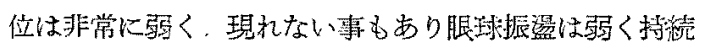
時間は長くない:

第 1 表 片側前莗直半規管灌流（腹位固定）

\begin{tabular}{|c|c|c|c|c|c|}
\hline 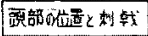 & 体温织差 & 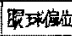 & 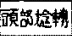 & 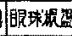 & 内㹯巨流れる方向 \\
\hline 体展位 $200^{40 \%}$ & $18^{\circ}$ & \# & \# & H & Ampullo tugaler St. \\
\hline 下斯位 $20 C^{4} 4 \%$ & $-180^{\circ}$ & + \pm & + \pm & $\#$ & Ampulto petaler St. \\
\hline 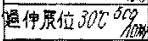 & $-8 \mathrm{C}$ & + \pm & + \pm & \# & Ampullo fugaler st. \\
\hline 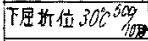 & $-8^{\circ} \mathrm{C}$ & \pm- & & + & Ampullo petaler St. \\
\hline 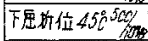 & $+7{ }^{\circ} \mathrm{C}$ & \pm- & \pm- & + & Ampulto fugaller $\Omega$. \\
\hline 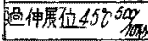 & $+7^{\circ} \mathrm{C}$. & - & - & + \pm & Ampullop \\
\hline
\end{tabular}

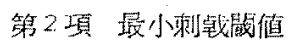

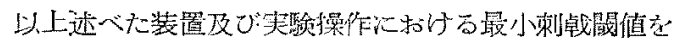

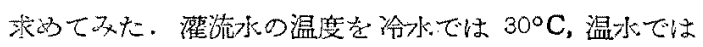

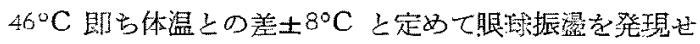
しるる最少の灌流水量老剆定すると, 各家束について固

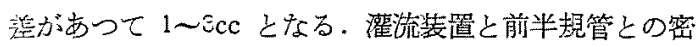

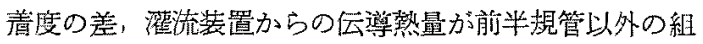

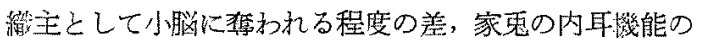
感要の差等古考炱られる。

\section{第 3 項 雨側耳同時刺战}

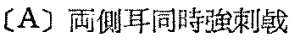

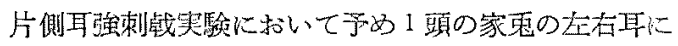

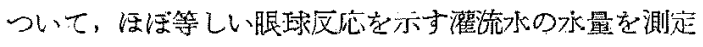
して未く、これを右 acc 左 bec とする. 最も反応の強

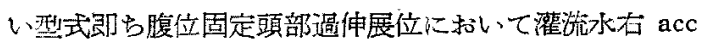

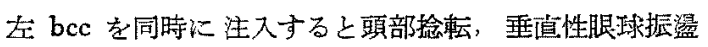

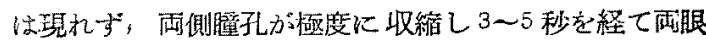

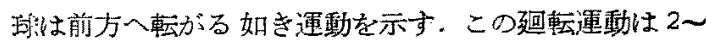
3回のみで終る:

[B] 両側耳同時弱刺戟

片側耳灌流では充分に腿淢振澄を発現する 水量即ら

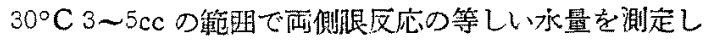

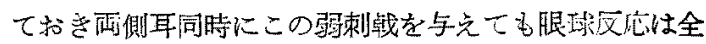
マ見られながった。

(C) 雨側耳異温度刺战

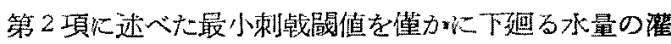

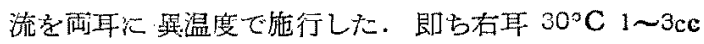

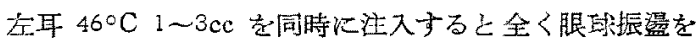
西さなからた例と, 明確に眼冰振蕰意発現した例とがあ り，この項については更に帛密な数多くの实虽を重ねな けれけ結果は不明である。

\section{第4章 考按}

Hitzig (1871) は家鬼の小脳小䈎を切断した㣰，該部

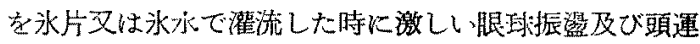
動を起こすのを罗て，小媨の刺㦸にるる結果でするとし

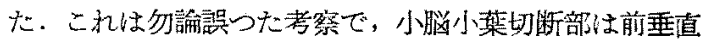
半規管輪部に該当するためこの所を水うで雌流子れば当

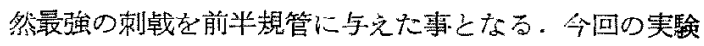

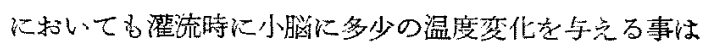
寲いないたか小脳の温度刺㦸による因子が的わる事は否 定できないが局温度の灌流を行つた时，頍部邀伯展位と

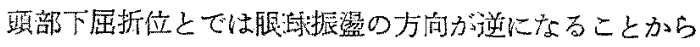

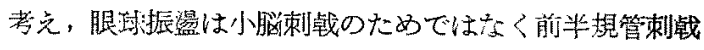

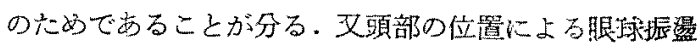

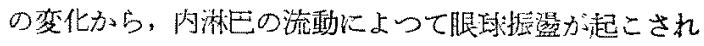
ている事が半然とする。

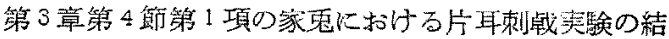
婪を綜合すると。

1) 家鬼一側前画半规管内淋巴の Ampullo fuga

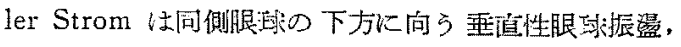

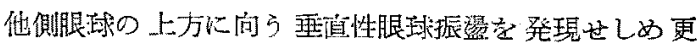

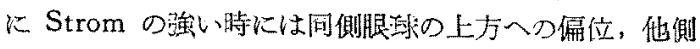

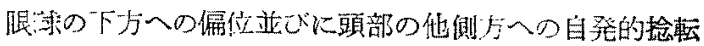

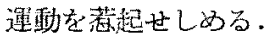

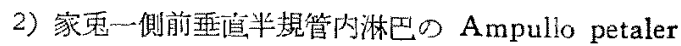

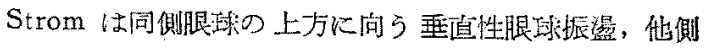

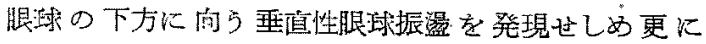

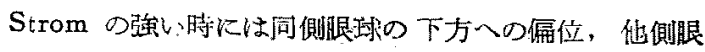

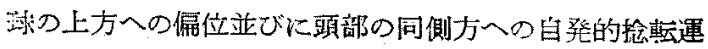




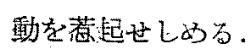

この時，腹拉固定 $20^{\circ} \mathrm{C}, 30^{\circ} \mathrm{C}, 45^{\circ} \mathrm{C}$ 备温度について

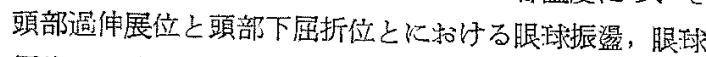
俪位，頭暗捻転等の強さ艺比较観察すると Ampullo fugaler Strom は Ampullo petaler Strom よりも強

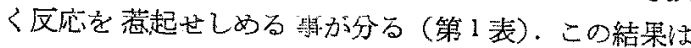
Ewald の説に一致する. Ampulla の感度の差加前垂俻

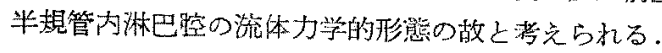

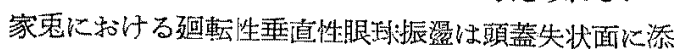

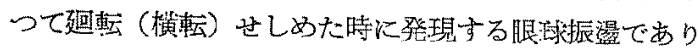
この場合の内淋巴流動は水平半想管に执いては起らず， 前後画垂直半規管内に执いて同時に発現する。人体にお

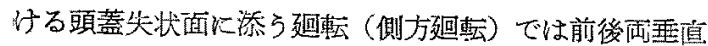
半規管内に同様の内桷巴流動を発現する事が考えられる

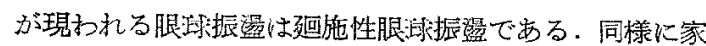

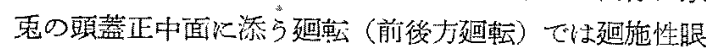

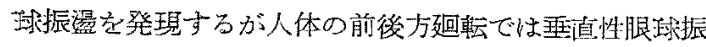

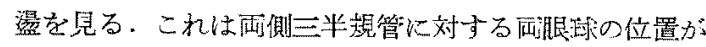
異る事によるもので家象では革側に人体では前方司一面

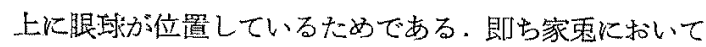
垂直性眼琲振璗を起すのと同一の条件老人体に与点ると

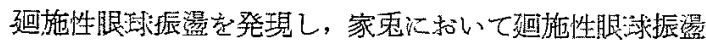

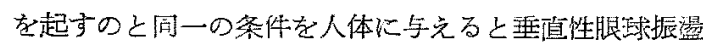

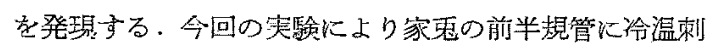

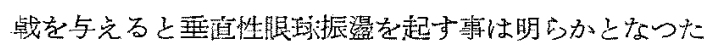

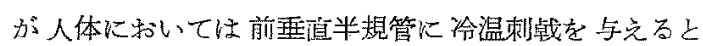

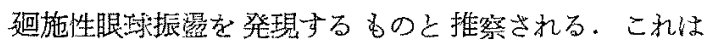

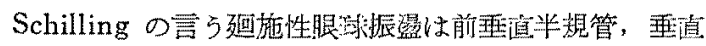

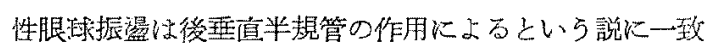

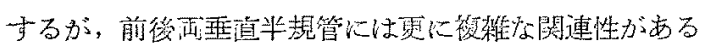

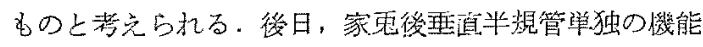

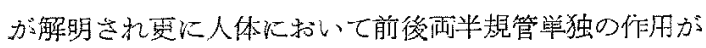
明らがなつた時叱判然とする閏题である。

水平面䢐転特には四側水平規管は共に迴転面内に位置 のるため网側同时に内鿟巴流動を起こす 垂直半規管に

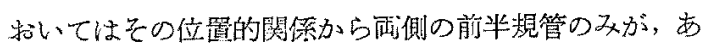
るいは雨側の後半規管の及が同時に内淋巴流動を起こす

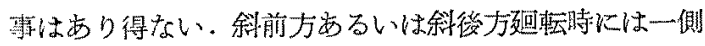

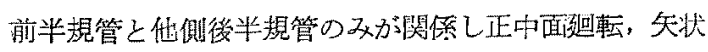

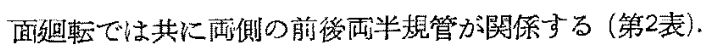

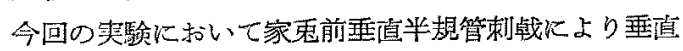
性眼球振温を発現する事は明確であるが両側同時刺战時

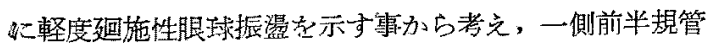

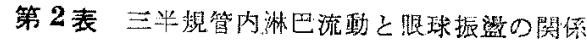
（迴轻誖性骐瑟振菹）

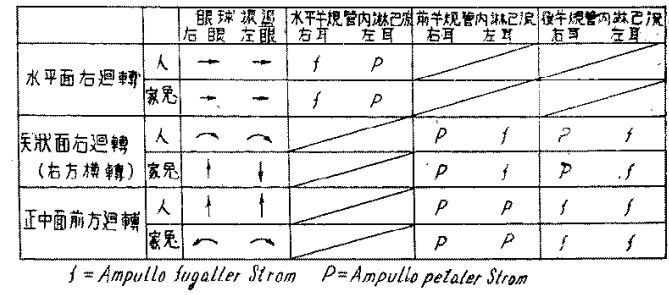

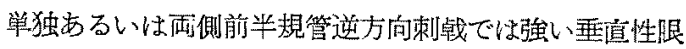

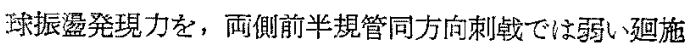
性腿冰振璗発現力を持つものと考察される。

\section{第 5 草 結諭}

1) 健䐂家乘について㱠ど正常の生活状態に就いて前

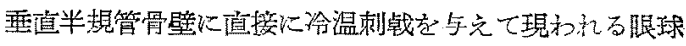
振湯索稓察した。

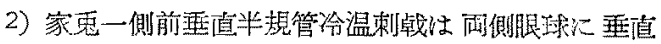

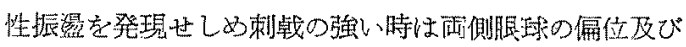

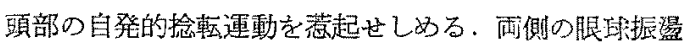
及び眼囦痛位の方向は逆方向である。

3) 前兲直半規管内淋巴流動は Ampullo petaler Strom は刺㦸弱く, Ampullo fugaler Strom は刺战 方強以。

4) 画側前垂直半規管内K Ampullo fugaler Strom が強く同時に起きた時，两側腿球は偏位主る霜なく強く

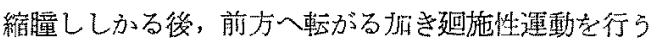
この運䡃の回数ば少い。

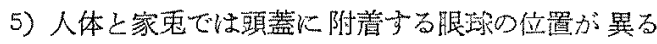

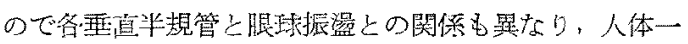

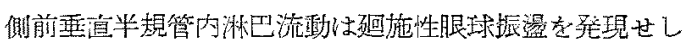
めるものと推察される。乙か乙前垂值半规管の之が廷施

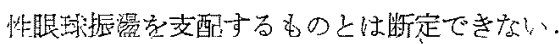

\section{参考 文 献}

1)大和田莚二郎：式鼻咽侯科，21 巻，7号，288，2)

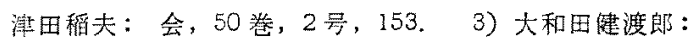

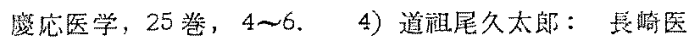

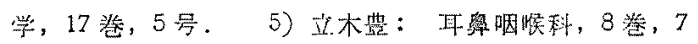

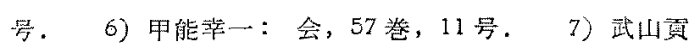
次：会, 56 替, 10 号. 8) 田原康出: 㕕, 60 巻, 10 号.99)唀本泰应: 会, 60 卷, 9号, 10) 小朾 清志: 十全医, 57 巻, 6号. 11) 安藤, 田嵒: 動物

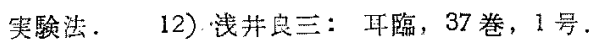




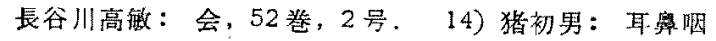

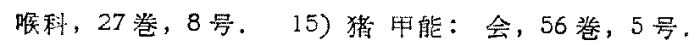

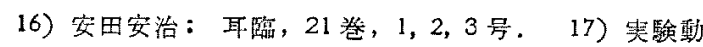

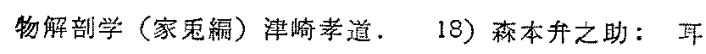

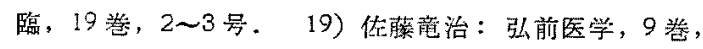

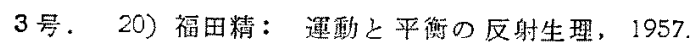
21) Stein Haúsen $W .:$ Arch f.d. ges. physiol. 232: 500, 1933. 22) Stein Hầsen W.: Arch f.d. ges. physiol. 228: 322, 1931. 23) Schmarz G.: Arch f. d. ges. physiol. 207, 1985. 24) Alexamder G. $\cong$ Marburg O.: Handbuch der Neūrologie des
Ohres Bd I, II, III 1924 6. 25) Fortochitt der: Hals-Nasen-Ohr. Heilkūnde 1953〜6, I. I.

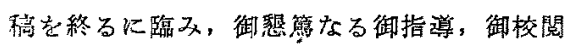
を賜わつた大藤敏三教授に深甚なる謝意を摔げ ると共に秏々御援助を仰いた滩町，平野学兄に 煘く感謝致します.

本諭文の要旨は第359回日本耳楀咽喉科関果 地方会例会に就いて発表した。

（原诖到着 $=$ 昭利 35.6 .13 日一急載） 


\section{田中論交付図 (I)}
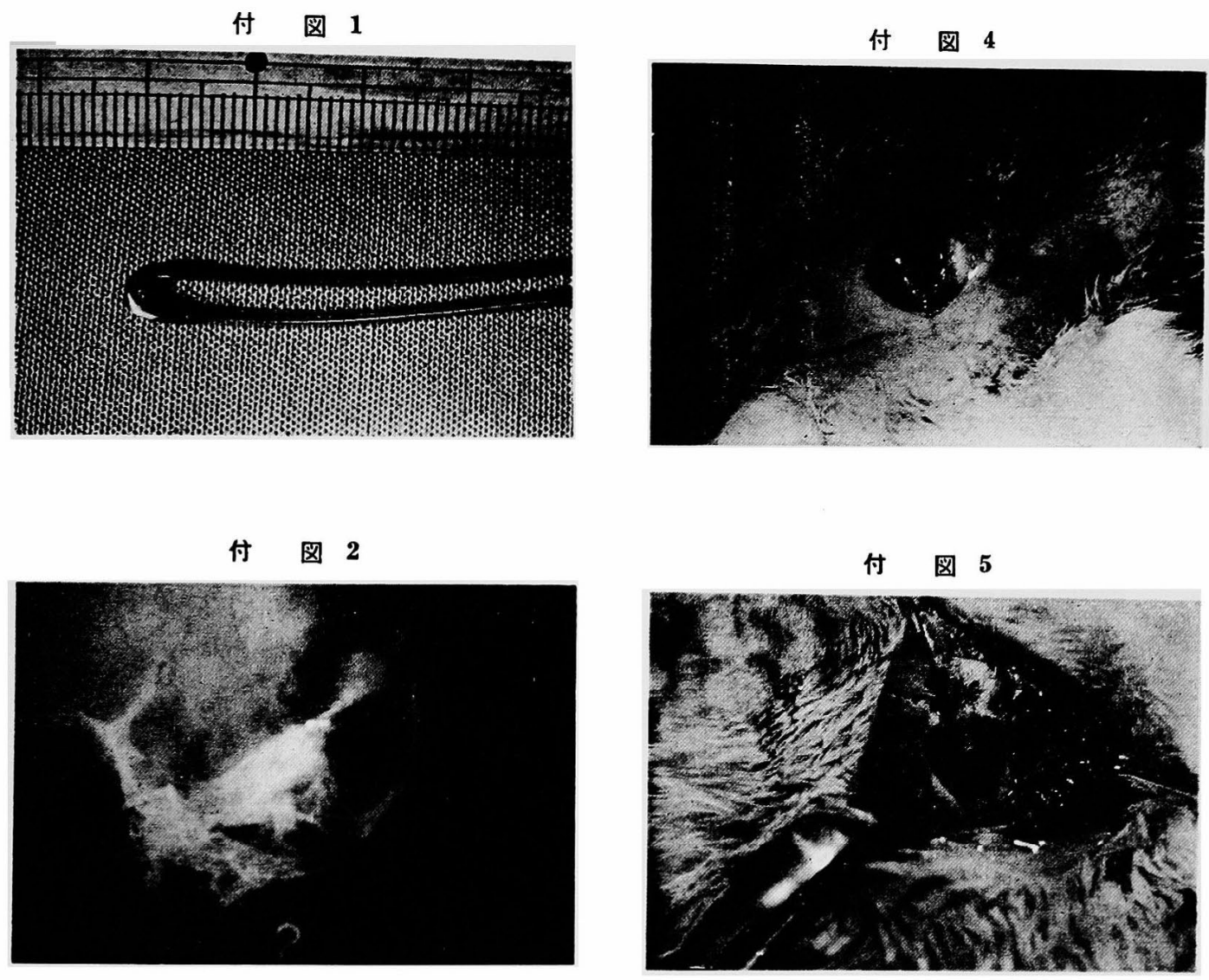

\section{付図 3}

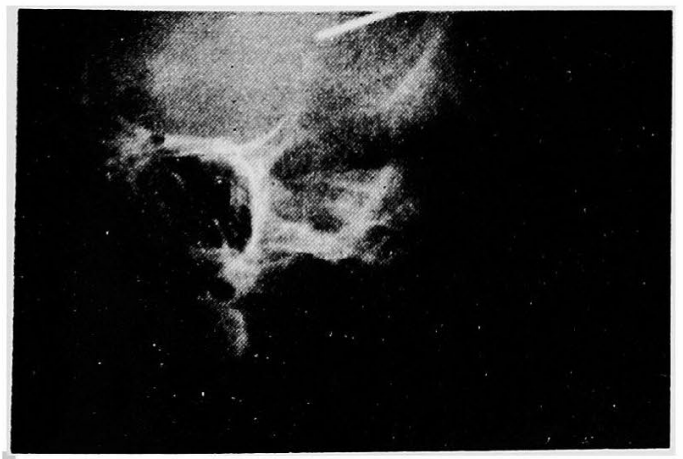

付图 6

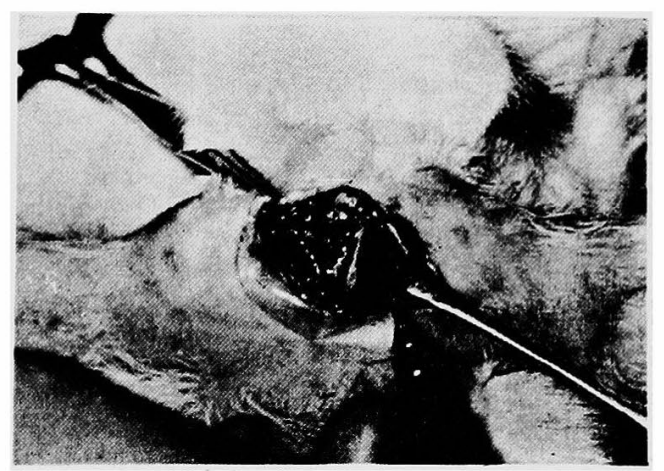


田中論交付図（II）
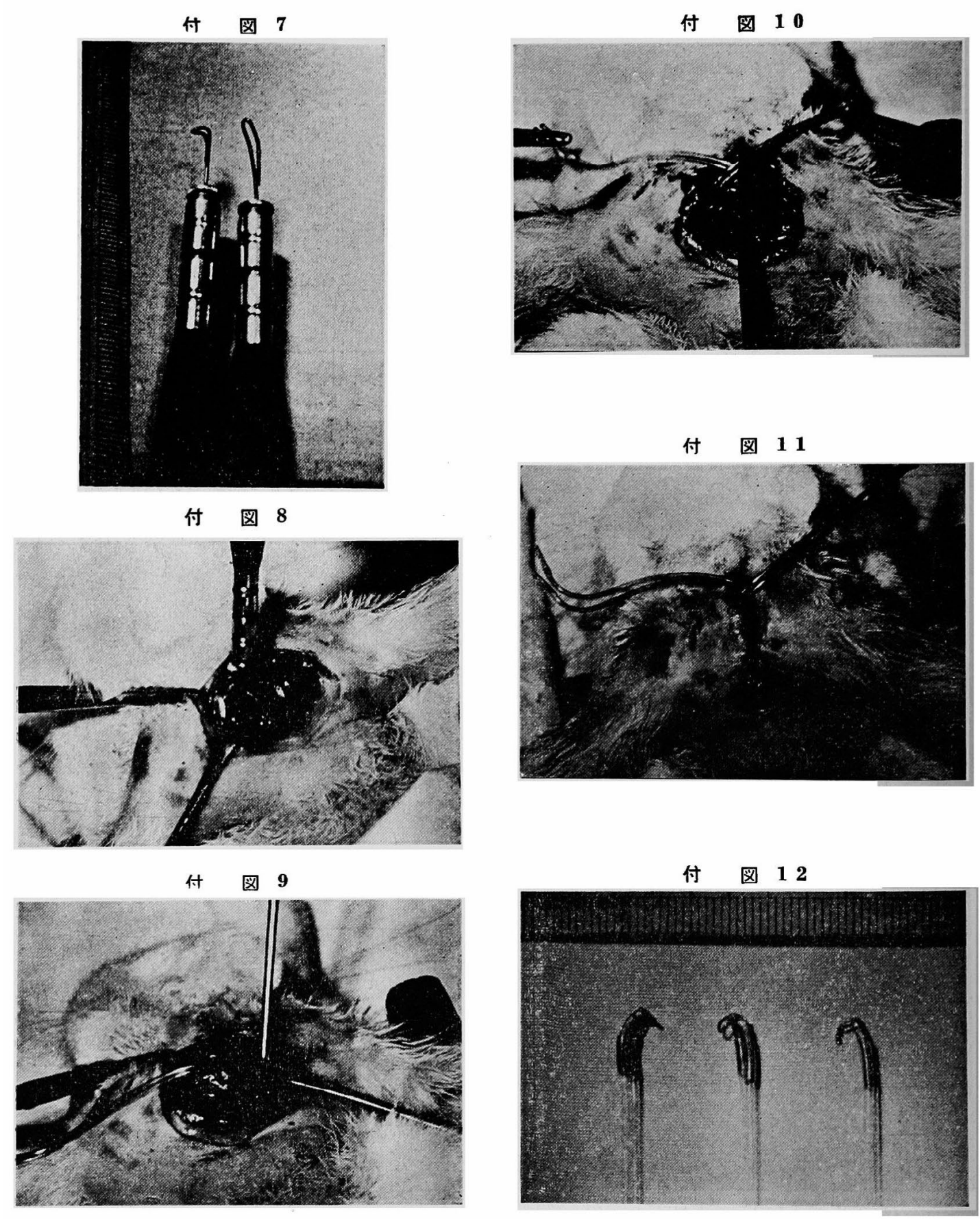
付图 13

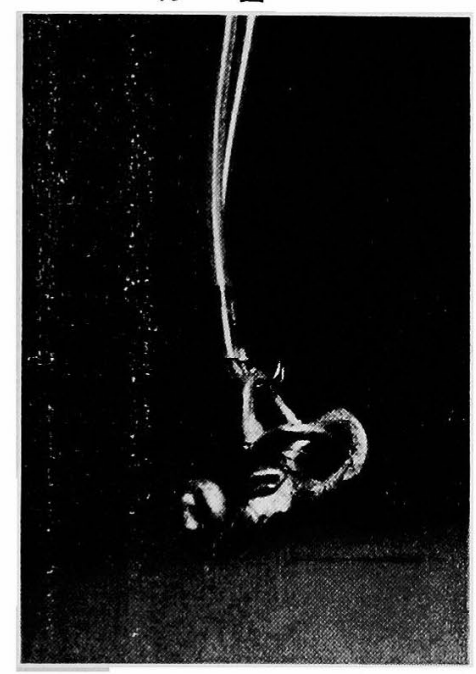

付図 14

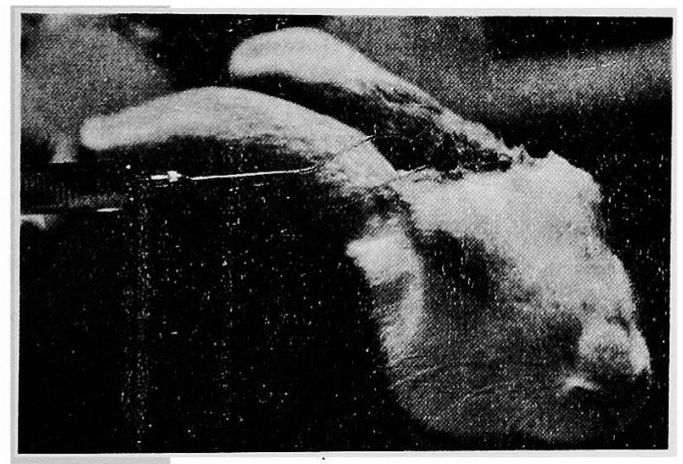

付図 15

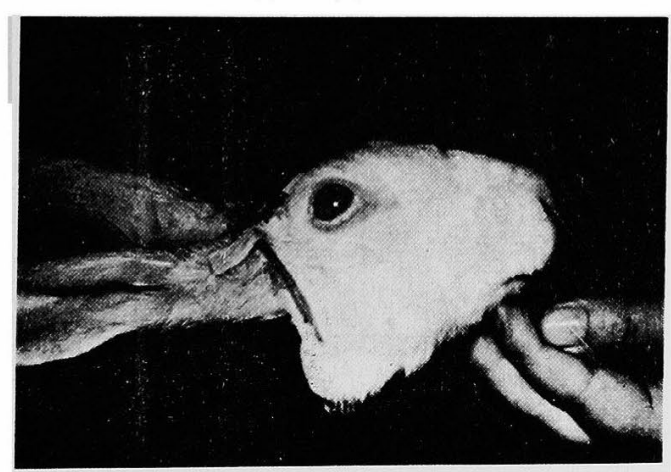

付图 16

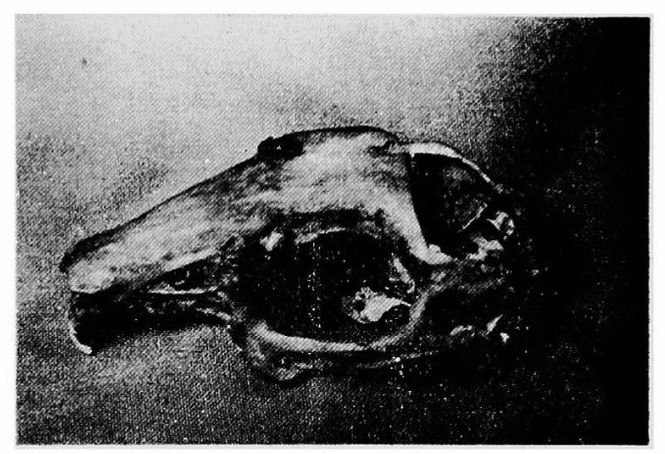

付图 17

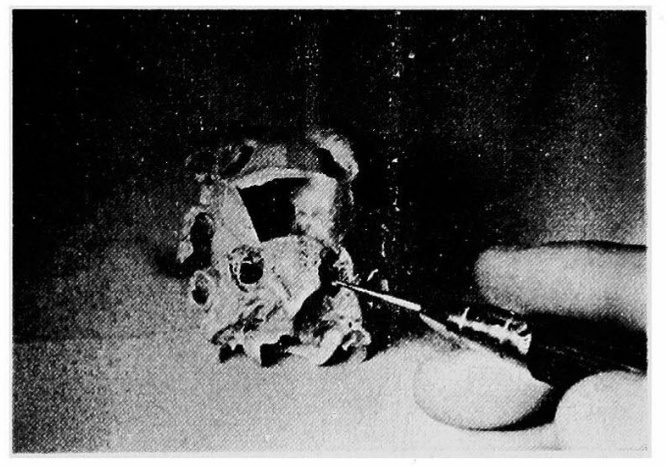

付図 18

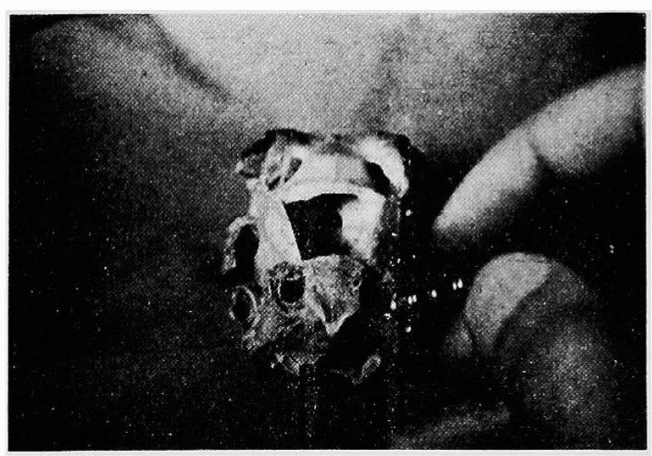


田中論交付図 (N)

付図 19

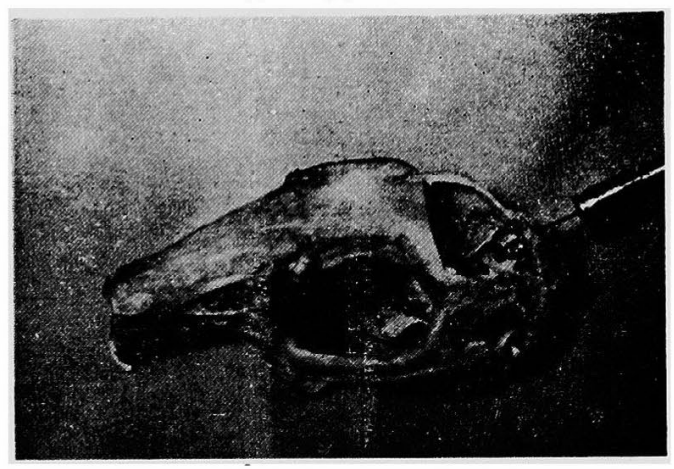

付图 20

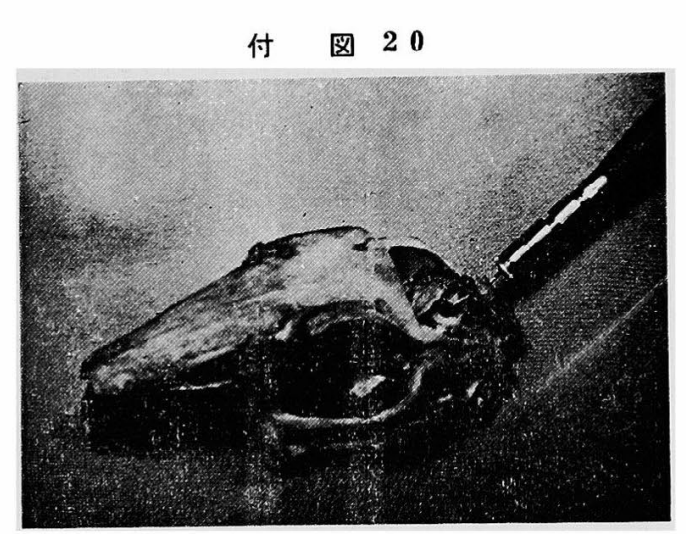

付図 21

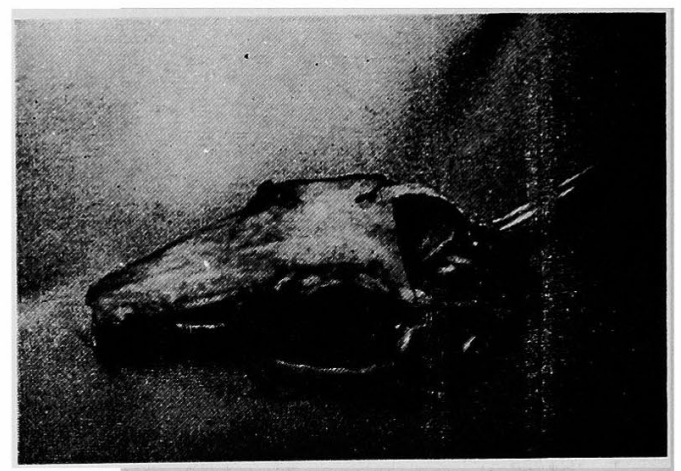


家鬼における手術法の図解

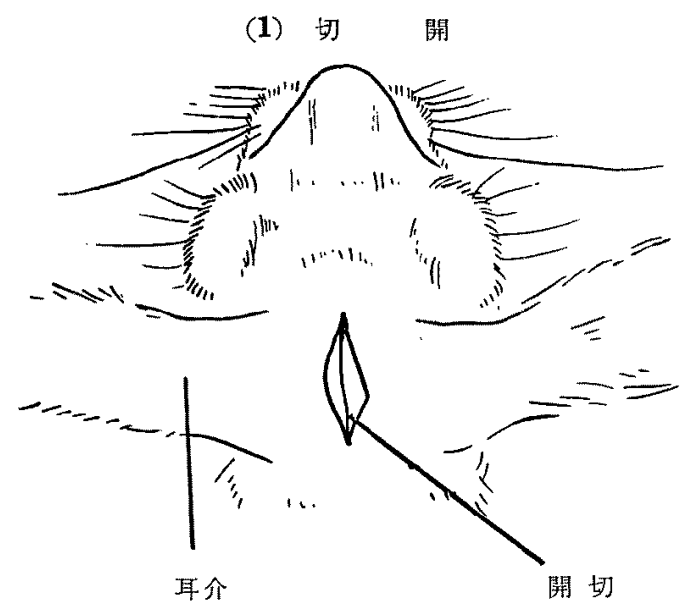

（2）䟝離 後頭結萿を露出せしめる

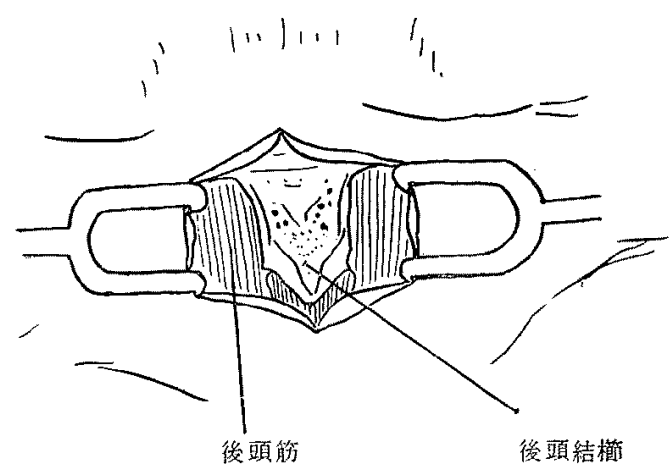

（4）両侧 鱗部を露出せしぬる

（3）後頭笳を影離
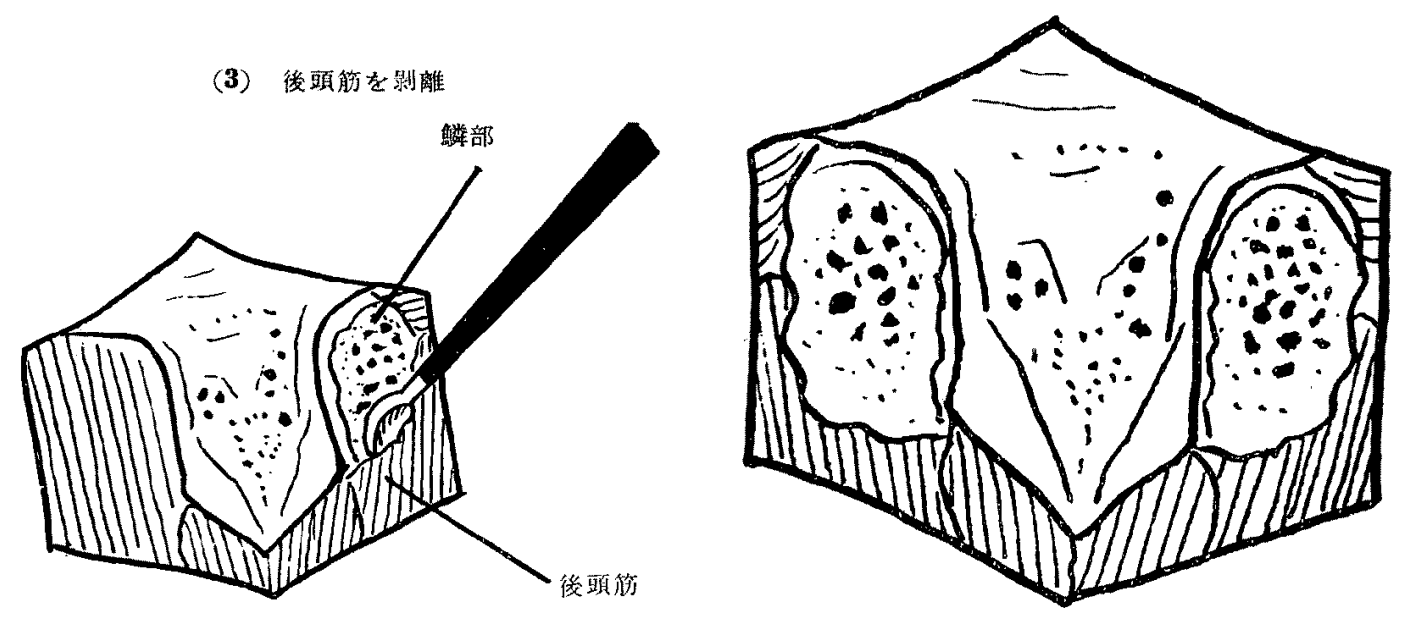

(6) 鱗部に孔を作る

（5）鱗部の鎴除
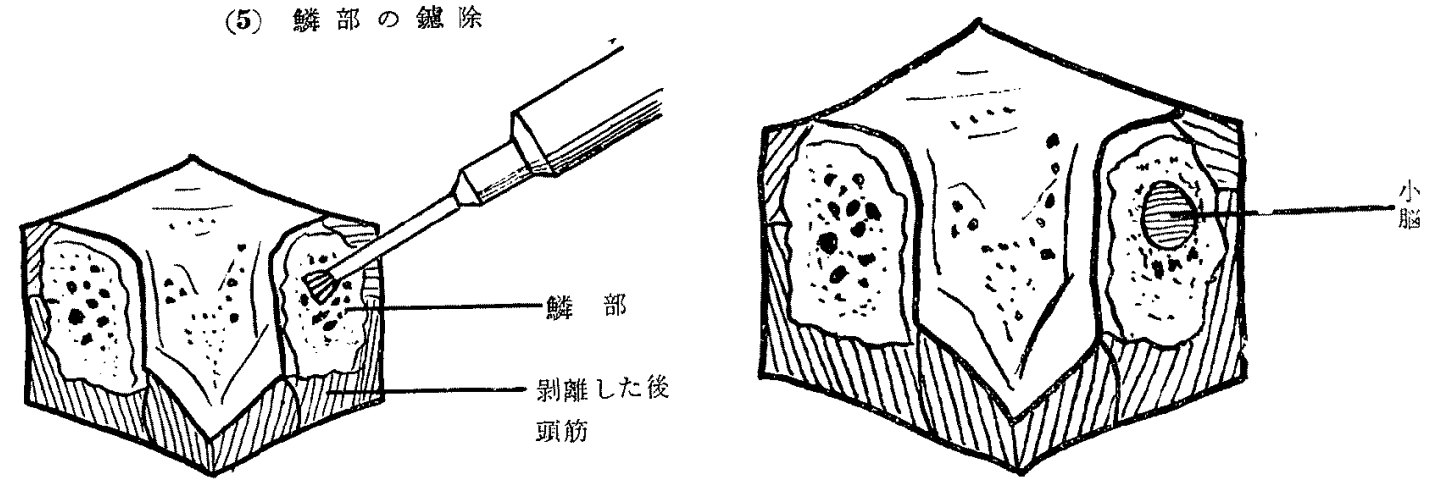
（7）穿孔を払大

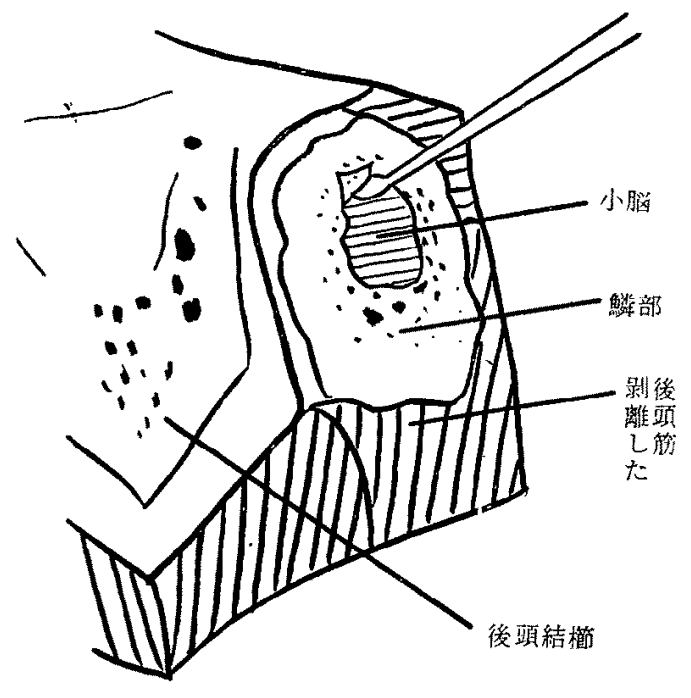

（9）頭蓋腔内骨膜虽離

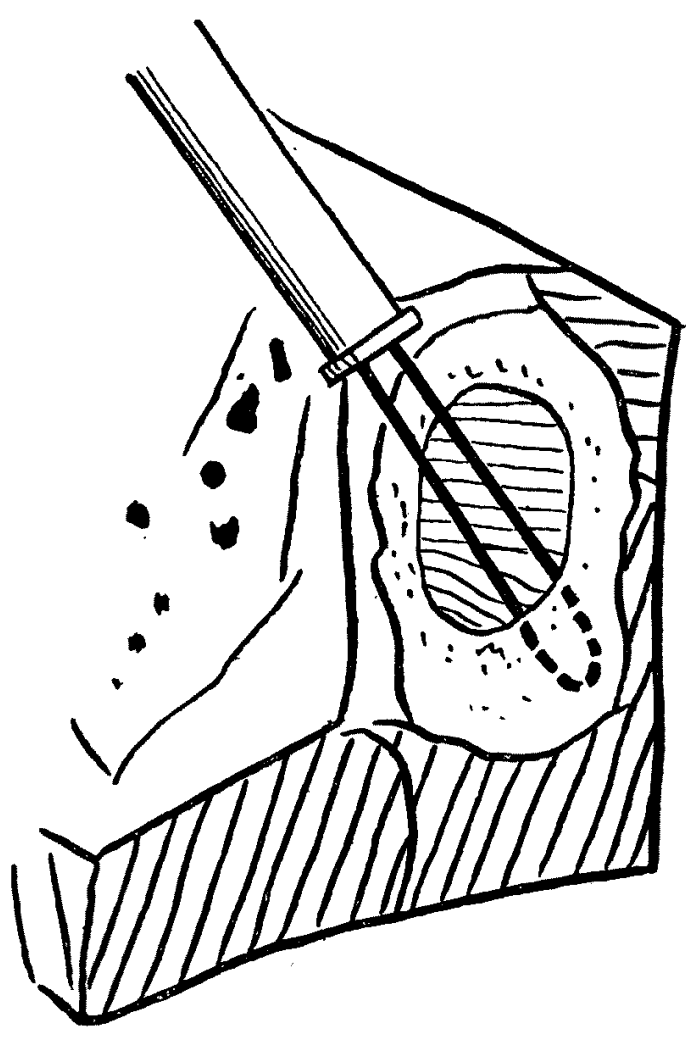

（8）小脳を広く露出せしめる

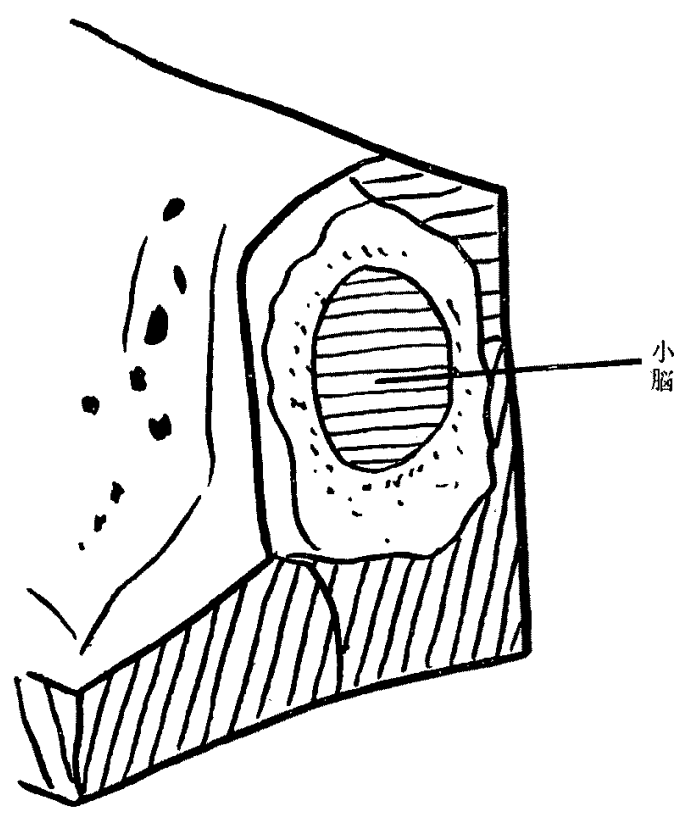

（10）灌流装直を聥入する

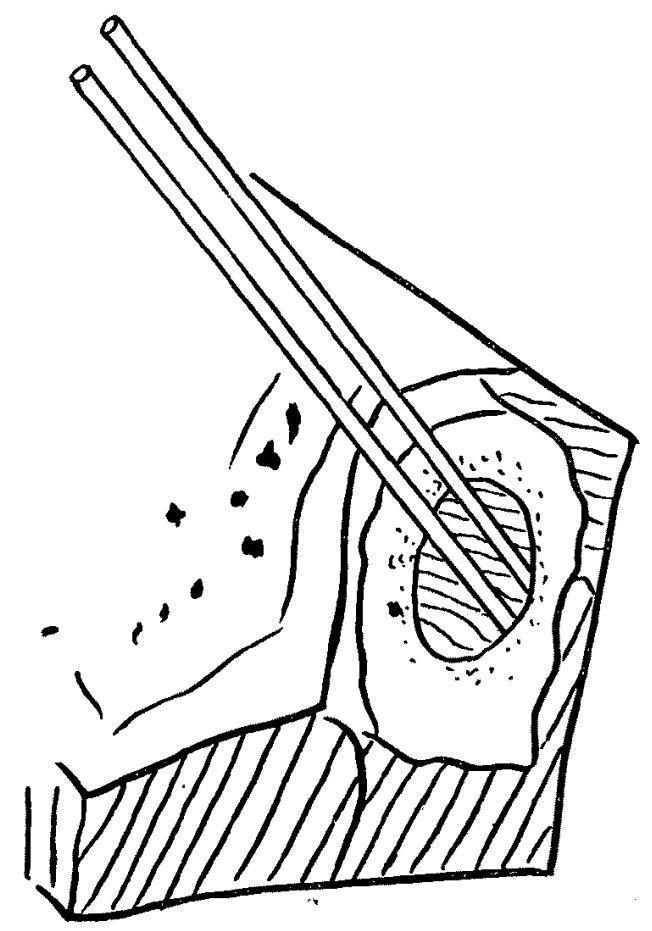


(11) 両侧に灌流装置插入

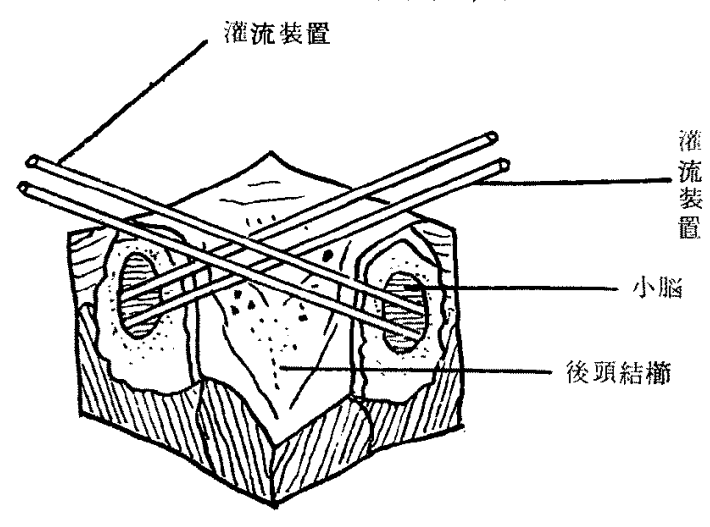

（12）灌流装置を固定，縋合

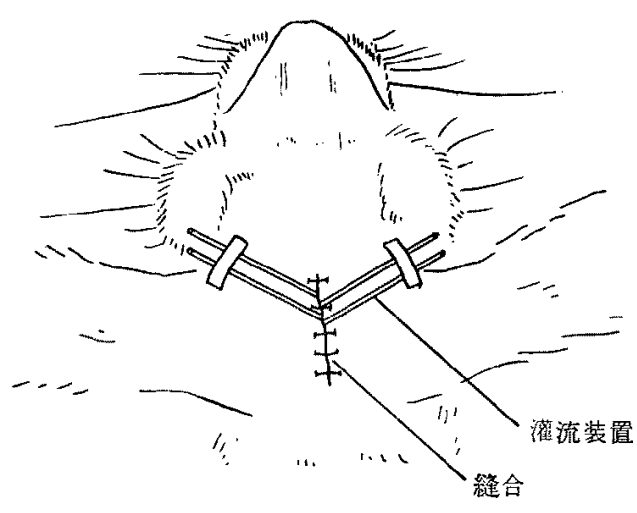

